\title{
Konferencja Naukowa „Osoba $z$ niepełnosprawnością w przestrzeni społecznej. Dwa światy - jedność w praktyce edukacyjno-rehabilitacyjnej, zawodowej i twórczej" (Warszawa, 19-20 października 2015 r.)
}

W dniach 19-20 października 2015 roku na Wydziale Nauk Pedagogicznych Uniwersytetu Kardynała Stefana Wyszyńskiego w Warszawie odbyła się konferencja naukowa poświęcona problematyce dotyczącej funkcjonowania osób z niepełnosprawnościami w różnych obszarach życiowych.

Konferencja była okazją do dzielenia się wynikami badań teoretycznych i empirycznych oraz doniesieniami z praktyki edukacyjnej, rehabilitacyjnej, zawodowej i twórczej osób z niepełnosprawnościami. Wśród uczestników czynnych konferencji znaleźli się pracownicy naukowi z następujących ośrodków: Uniwersytet Adama Mickiewicza (UAM) w Poznaniu, Uniwersytet Marii Curie-Skłodowskiej (UMCS) w Lublinie, Akademia Pedagogiki Specjalnej (APS) w Warszawie, Uniwersytet Rzeszowski (URz), Uniwersytet Wrocławski (UWr), Uniwersytet Śląski (UŚ), Uniwersytet Szczeciński (Usz), Uniwersytet Pedagogiczny im. Komisji Edukacji Narodowej (UP KEN) w Krakowie, Uniwersytet Kardynała Stefana Wyszyńskiego (UKSW) w Warszawie, a także przedstawiciele instytucji: Fundacja l'Arche, Ośrodek Rozwoju Edukacji w Warszawie, Komenda Miejska Państwowej Straży Pożarnej w Olsztynie.

Uroczystego otwarcia dwudniowej konferencji dokonała dziekan WNP UKSW, kierownik Katedry Pedagogiki Specjalnej i Integracyjnej Jadwiga Kuczyńska-Kwapisz. Słowa powitania wygłosił również prorektor UKSW Jerzy Cytowski. Inaugurację uświetnił występ artystyczny uczniów z Zespołu Szkół Specjalnych nr $90 \mathrm{w}$ Warszawie.

Pierwszą część obrad plenarnych poprowadziła Jadwiga Kuczyńska-Kwapisz, przewodnicząca komitetu naukowego konferencji. Zaprezentowane zostały cztery referaty. Jan Piskurewicz (UKSW w Warszawie) omówił temat: Społeczeństwo wobec osób z niepełnosprawnością. Perspektywa historyczna. Po nim współczesną perspektywę oglądu zjawisk związanych z niepełnosprawności podjęła Maria Chodkowska (UMCS w Lublinie) w wystąpieniu pt. Aksjologiczne dylematy niepełnosprawności w postintegracyjnej przestrzeni społecznej. W następnym referacie 
Iwona Chrzanowska (UAM w Poznaniu) analizowała kwestię efektywności edukacji inkluzyjnej uczniów o specjalnych potrzebach edukacyjnych (Edukacja właczajaca dzieci i młodzieży z niepełnosprawnościa - refleksje). Ostatnim wystąpieniem tej części obrad była prezentacja Roli czynników niepełnosprawności w budowaniu umysłowych reprezentacji kategorii społecznych (Nawoja Mikołajczak-Matyja, UAM w Poznaniu).

W drugiej części obrad plenarnych, której przewodniczył Stanisław Chrobak, występowali przedstawiciele UKSW w Warszawie. W referacie Eugeniusza Sakowicza podjęta została kwestia stosunku do osób niepełnosprawnych w różnych kulturach świata. Z kolei Anna Fidelus zaprezentowała model relacyjnej inkluzji społecznej, analizując rolę zasobów wewnętrznych i zewnętrznych jednostek istotnych dla powodzenia tego procesu. W ostatnim referacie tej części obrad Edyta Wolter zaprezentowała temat „Uczyć się, aby żyć wspólnie” w koncepcji Międzynarodowej Komisji ds. Edukacji XXI wieku.

Referaty naukowe wygłoszone podczas obrad plenarnych stały się ramą analityczną dla dyskusji podczas dwóch równoległych sekcji tematycznych. W pierwszej sekcji zajęto się problemami osób niewidomych i słabowidzących w przestrzeni edukacyjno-rehabilitacyjnej. W szczególności dyskutowano zagadnienia rehabilitacji i edukacji osób z dysfunkcją wzroku w dobie rozwoju nauki i nowych technologii, społecznej roli technologii wspomagających w kontekście edukacji ogólnodostępnej oraz współczesnych tendencji w tyflopedagogice. Prelegenci zwrócili szczególną uwagę na praktykę pedagogiczną dotyczącą wsparcia edukacyjno-rehabilitacyjnego ucznia ociemniałego z niepełnosprawnością wielozakresową. Ponadto omówiono wyniki badań empirycznych poświęconych postawie młodzieży słabowidzącej wobec trudnych sytuacji życiowych.

W ramach drugiej sekcji zajęto się tematem aktywności twórczo-artystycznej osób z niepełnosprawnościami. Analizowano twórczość plastyczną artystów z niepełnosprawnościami, znaczenie tejże twórczości w przestrzeni publicznej, a także wkład instytucji kultury w promowanie sztuki osób z niepełnosprawnością intelektualną. Podjęta została także kwestia działań artystycznych w resocjalizacji penitencjarnej. Zwieńczeniem obrad w tej sekcji był referat poświęcony działalności artystycznej uczniów i studentów z niepełnosprawnościami.

Rozwinięciem i dopełnieniem konferencji były warsztaty twórczo-metodyczne: warsztat plastyczny „Druga strona lustra”, muzyczno-ceramiczny Ceramiczne nuty... czyli jak z gliny zrobić instrument muzyczny oraz teatralny Jak wprowadzić przedszkolaki wświat niewidomych osób.

W drugim dniu konferencji obrady plenarne moderował Jerzy Stochmiałek (UKSW w Warszawie). W ich trakcie wygłoszono trzy referaty. Stanisława Byra i Monika Parchomiuk (UMCS w Lublinie) zaprezentowały wyniki badań poświęconych stygmatyzacji przeniesionej (Stygmatyzacja przeniesiona a obraz siebie partnerów osób z niepełnosprawnością ruchowa), Iryna Kurlak (UKSW w Warszawie) omówiła temat Więzienna służba zdrowia $w$ trosce o stan osób przewlekle chorych, 
zaburzonych i niepełnosprawnych, a Małgorzata Paplińska (APS w Warszawie) zajęła się sytuacją osób niewidomych jako odbiorców sztuk wizualnych (Niewidomy odbiorca sztuki - społeczne, edukacyjno-rehabilitacyjne znaczenie udostępniania przedstawień teatralnych i filmów dla osób z niepetnosprawnością wzrokowa).

Po obradach w plenum odbyły się spotkania w czterech równoległych sekcjach tematycznych. Pierwsza sekcja dotyczyła problematyki osób z niepełnosprawnościami w procesie wielospecjalistycznego wspierania. Dyskutowano w niej na temat edukacji seksualnej jako elementu wspomagania rozwoju osób z niepełnosprawnością intelektualną, wybranych metod terapii w procesie leczenia osób przewlekle chorych, rehabilitacji społeczno-zawodowej osób autystycznych oraz terapii dzieci, młodzieży i dorosłych z zespołem Aspergera.

Podczas obrad drugiej sekcji podjęto się rozważań dotyczących funkcjonowania osób z niepełnosprawnościami w różnych fazach życia. Analizowano autopercepcję dzieci z chorobą przewlekłą, udział rodziców w procesie wczesnego wspomagania rozwoju, proces powstawania, główne założenia i wybrane praktyki standardów jakości życia w domach o charakterze rodzinnym dla dorosłych osób z niepełnosprawnością intelektualną oraz potrzebę towarzyszenia osobom z niepełnosprawnością w drodze ku lepszemu życiu i dorosłości.

Osoby z niepełnosprawnościami w obszarze rekreacji i aktywności zawodowej to motyw przewodni obrad, które toczyły się w trzeciej sekcji tematycznej. W jej ramach przedyskutowano zagadnienia aktywności osób z niepełnosprawnością w czasie wolnym w zróżnicowanych przestrzeniach edukacyjno-rehabilitacyjnych (raport badawczy), elastycznych form zatrudnienia i organizacji pracy jako szansy na aktywizację społeczno-zawodową osób niepełnosprawnych, aktywizacji zawodowej osób niepełnosprawnych w modelu zatrudnienia wspomaganego oraz resocjalizacji skazanych w obecności osób niepełnosprawnych.

Ostatnia sekcja poświęcona była problemom osób z niepełnosprawnościami sensorycznymi w przestrzeni edukacyjno-rehabilitacyjnej. Głównym wątkiem dyskusji było funkcjonowanie studentów z niepełnosprawnością na uczelniach wyższych w kontekście aktualnych doświadczeń, potrzeb i wyzwań.

Zwieńczeniem dyskusji w sekcjach tematycznych było plenum podsumowujące. Oprócz zaprezentowania wniosków z prac w sekcjach, wygłoszone zostały trzy prelekcje. Jako pierwsza głos zabrała Dorota Żyro, wicedyrektor Ośrodka Rozwoju Edukacji, temat jej wystąpienia to: Podnoszenie efektywności ksztatcenia uczniów ze specjalnymi potrzebami edukacyjnymi w Polsce. Następnie Maciej Hamerski, naczelnik Wydziału Kontrolno-Rozpoznawczego Komendy Miejskiej Państwowej Straży Pożarnej w Olsztynie, omówił procedury bezpieczeństwa w placówkach zajmujących się opieką, wychowaniem, edukacją i rehabilitacją osób z niepełnosprawnościami. Konferencję zakończył pobudzający do refleksji referat Witolda Starnawskiego pt.: Niepełnosprawność - czym jest (może być) dla osób w pełni sprawnych.

Podsumowując, można stwierdzić, że zaprezentowana konferencja stała się rzeczywistym forum umożliwiającym eksplorację i aktualizację kluczowych 
zagadnień, ważnych z punktu widzenia normalizacji życia osób z niepełnosprawnościami, a także projektowania przestrzeni społecznej dla ich aktywizacji, samorealizacji oraz pełnoprawnego dostępu do dóbr, usług i oferty kulturowej.

Emilia Śmiechowska-Petrovskij

UKSW, Warszawa 